\title{
Food Handling Practice of Culinary Merchants in Medan, Indonesia
}

\author{
Patrick Limbardon ${ }^{1}$, Nenni Dwi Aprianti Lubis ${ }^{2 *}$, Rina Amelia ${ }^{3}$, Sri Amelia ${ }^{4}$ \\ Corresponding Email: nenni@usu.ac.id \\ ${ }^{1}$ Faculty of Medicine, Universitas Sumatera Utara, Medan, Indonesia \\ ${ }^{2}$ Department of Nutrition, Faculty of Medicine, Universitas Sumatera Utara, Medan, \\ Indonesia \\ ${ }^{3}$ Department of Community Medicine/Public Health Faculty of Medicine, Universitas \\ Sumatera Utara, Medan, Indonesia \\ ${ }^{4}$ Department of Microbiology, Faculty of Medicine, Universitas Sumatera Utara, Medan, \\ Indonesia \\ Received: November 23, 2021 \\ Received in Revised: December 21, \\ 2021 \\ Accepted: January 25, 2022
}

\begin{abstract}
Indonesian Food and Drug Supervisory Agency (BPOM) estimates that over 20 million incidences of poisoning occur yearly in Indonesia. In 2019, food poisoning was the cause of 17 out of 154 poisoning incidents in Medan. This study aims to picturize food safety practice among food handlers at culinary merchants. Using a descriptive, cross-sectional study, a total of 52 samples were given a survey with a total of 35 questions regarding characteristic of samples, food safety knowledge, food management attitude, and food management practice. The data collected were $73,1 \%$ the food-handlers had average knowledge level of food safety, 92.3\% had a good attitude in food management, 53,8\% had average level of food management practice, and $51.9 \%$ had a good behavior in food management. There are still chances for cross contamination to occurs. In order to ensure the safety of sold products, food handling training and rules should be prioritized and advocated.
\end{abstract}

Keywords: Cross Contamination, Culinary, Food Handling, Food Safety

\section{Introduction}

Unsafe food causes up to 200 diseases ranging from diarrhea to cancer (WHO, 2020). The WHO estimated that it causes 600 million morbidities and 240 thousand mortalities every year. In the United States alone, foodborne diseases are responsible for 76 million illnesses, 325.000 in-hospital patients, and 5.000 deaths (Kadariya et al., 2014). In Indonesia, the Food and Drug Supervisory Agency (BPOM) estimated that over 20 million incidences of poisoning occur annually (BPOM RI, 2020). Furthermore, according to a systematic review of 175 papers on exceptional cases of food poisoning in Indonesia from 2000 to 2015, 82 incidents (46.9\%) originated from home cooking. Catering services were responsible for 33 occurrences $(18.9 \%)$, while street food was responsible for $32(18.3 \%)$. The rest were caused by non-home industry food, industrial food for the household, Islamic boarding school kitchens, and refugee camps (Arisanti, 2018). In 2019, food poisoning was the cause of 17 out of 154 poisoning incidents in Medan (BPOM Medan, 2020)

Food poisoning symptoms range from minor and temporary, such as nausea, vomiting, and malaise, to life-threatening such as renal failure, paralysis, and nervous system and brain

Copyright $@$ (2022, Journal of Asian Multicultural Research for Medical and Health Science Study, Under the license CC BY-SA 4.0 
dysfunction (Chlebicz, 2018). Foodborne disease can be classified as either an infection or intoxication. When live microbes are ingested, they thrive in the human body, which causes food-borne diseases. In addition, when microbial or naturally occurring toxins are eaten in contaminated foods, they produce intoxication. A group of illnesses associated with eating foods contaminated with chemical poisons or microbes are referred to as food poisoning (Gibney et al., 2009).

There are several factors that increase the incidence of foodborne disease. The microbial factors include the type, strain, and the number of pathogens eaten. Host factors include young or old age ( $<5$ years old or $>50-60$ years old), pregnancy, in-hospital care, co-infection, antibiotic usage, high serum iron, decrease in liver/ kidney function, alcohol, duplicating specific human antigen determinant, removal of part of the stomach or the intestines, immunodeficiency, stress, and poor hygiene. Food-related factors include nutritional deficiency either due to defects in nutritional absorption or unavailability of adequate food supply, antacid usage, overconsumption of water, or pathogen-containing fatty food. Furthermore, the other factors are geographic (WHO, 2002).

Thirty-one foodborne threats which caused 32 diseases were included in the worldwide estimates, with 11 diarrheal disease agents ( 1 virus, 7 bacteria, 3 protozoa), 7 invasive infectious disease agents ( 1 virus, 5 bacteria, 1 protozoon), 10 helminths, and 3 chemicals. The most common causes of food poisoning include diarrheal disease agents, particularly norovirus and Campylobacter spp. These agents caused 230,000 deaths, particularly non-typhoidal Salmonella enterica. Salmonella Typhi, Taenia solium, hepatitis A virus, and aflatoxin were also prominent causes of foodborne mortalities (WHO, 2015). Food contamination also occurs as a result of pollutants in the air, water, and soil, such as hazardous metals, polychlorinated biphenyls (PCBs), and dioxins. Other chemical dangers, such as naturally occurring toxicants, may occur at any time during the production, harvesting, processing, or preparation of food (WHO, 2013). This study aimed to determine the picture of culinary merchant worker's food safety practices

\section{Methods}

This is a descriptive, cross-sectional study. A survey was carried out to ascertain information on the safety practices of food merchant workers. The type of data collected was primary and included the characteristic of samples, food safety knowledge, food management attitude, and food management action. This data was obtained by answering questions via a validated questionnaire. Furthermore, questions on food safety knowledge and food management action were adopted and modified from Angolo study (Angolo, 2011). The reliability of these questions was tested with the value of Cronbach's alpha 0.747 and 0.718 consecutively. Questions on food management attitude were also adopted and modified from Augustin study with the value of Cronbach's alpha 0.968 (Augustin, 2014).

There were 15 multiple choice questions on food safety knowledge with each containing 4 choices $(0=$ false, $1=$ true). Subsequently, there were 10 questions on food management attitude ( $1=$ agree, $0=$ disagree). Lastly, there were 10 questions on food management action using a 5-point Likert scale ( $4=$ always, $3=$ often, $2=$ sometimes, $1=$ rarely, $0=$ never $)$.

The survey and consent were printed and distributed to respondents in July 2021. This survey was designed to take 10 to 15 minutes to complete. Samples were recruited $(n=51)$ with consecutive sampling methods and calculated using Slovin's formula. This study was conducted in one of the food cafeterias in Medan. 
Data were analyzed using IBM SPSS Statistics software. Furthermore, variables were assessed univariately and the descriptive data were reported as actual counts and the percentage of respondents

\section{Results and Discussion}

\section{Characteristic of Respondent}

Table 1. Characteristic of food handlers in Medan, Indonesia

\begin{tabular}{|c|c|c|}
\hline \multicolumn{3}{|c|}{ Characteristics of Respondents } \\
\hline Gender & Frequency (person(s)) & Percentage $(\%)$ \\
\hline Male & 13 & 25 \\
\hline Female & 39 & 75 \\
\hline Total & 52 & 100 \\
\hline \multicolumn{3}{|l|}{ Age } \\
\hline $6-11$ & 0 & 0 \\
\hline $12-16$ & 1 & 1.9 \\
\hline $17-25$ & 25 & 48.1 \\
\hline $26-35$ & 11 & 21.2 \\
\hline $36-45$ & 10 & 19.2 \\
\hline $46-55$ & 3 & 5.8 \\
\hline $56-65$ & 2 & 3.8 \\
\hline $66-100$ & 0 & 0 \\
\hline Total & 52 & 100 \\
\hline \multicolumn{3}{|l|}{ Education } \\
\hline Elementary school & 1 & 1.9 \\
\hline Junior high school & 2 & 3.8 \\
\hline Senior high school & 41 & 78.8 \\
\hline College & 8 & 15.4 \\
\hline Total & 52 & 100 \\
\hline \multicolumn{3}{|l|}{ Information sources } \\
\hline Books/ Magazines & 5 & 9.6 \\
\hline Friends & 21 & 40.4 \\
\hline TV & 8 & 15.4 \\
\hline Formal education & 11 & 21.1 \\
\hline Internet & 4 & 7.7 \\
\hline Other & 3 & 5.8 \\
\hline Total & 52 & 100 \\
\hline \multicolumn{3}{|l|}{ Type of merchandise } \\
\hline Rice & 17 & 32.7 \\
\hline Noodle & 11 & 21.2 \\
\hline Snack & 24 & 46.2 \\
\hline Total & 52 & 100 \\
\hline
\end{tabular}

Respondents were required to fill in their identities such as gender, age, education, and information source. Table 1 shows the characteristics of respondents. The majority of the

Copyright $\odot$ 2022, Journal of Asian Multicultural Research for Medical and Health Science Study, Under the license CC BY-SA 4.0 
respondents were female $75 \%$ (39/52). Most studies have reported a higher proportion of female involvement in food handling (Ncube et al., 2020, Akabanda et al., 2017). In this study, the age of all respondents ranged between 16 to 65 years old with the majority from late adolescent (17 years old to 25 years old). The majority of the respondents' last formal education was senior high school $78.8 \%$ (41/52). Friends, formal education, and television were the primary food-management sources for most respondents $76.9 \%(40 / 52)$ with the majority from friends $40.4 \%$ (21/52).

\section{Food Safety Knowledge}

Table 2. Assessment of food safety knowledge of food handlers in Medan, Indonesia

\begin{tabular}{|c|c|c|c|c|}
\hline \multirow[b]{2}{*}{ Questions } & \multicolumn{4}{|c|}{ Frequency } \\
\hline & $\begin{array}{c}\text { Correct } \\
\text { (number of } \\
\text { item) }\end{array}$ & $\begin{array}{c}\text { Percentage } \\
(\%)\end{array}$ & $\begin{array}{c}\text { Wrong } \\
\text { (number of } \\
\text { item) }\end{array}$ & $\begin{array}{c}\text { Percentage } \\
(\%)\end{array}$ \\
\hline $\begin{array}{l}\text { Where do the risks for } \\
\text { food contamination } \\
\text { exist? }\end{array}$ & 26 & 50 & 26 & 50 \\
\hline $\begin{array}{l}\text { How is the condition of } \\
\text { food with enough } \\
\text { bacterial contamination } \\
\text { to cause foodborne } \\
\text { illness in susceptible } \\
\text { persons? }\end{array}$ & 11 & 21.2 & 41 & 78.8 \\
\hline $\begin{array}{l}\text { Which one of the } \\
\text { following is safe for } \\
\text { food? }\end{array}$ & 46 & 88.5 & 6 & 11.5 \\
\hline $\begin{array}{l}\text { Where should thawing } \\
\text { raw meat be stored? }\end{array}$ & 19 & 36.5 & 33 & 63.5 \\
\hline $\begin{array}{l}\text { Under what conditions } \\
\text { should food storage be? }\end{array}$ & 51 & 98.1 & 1 & 1.9 \\
\hline $\begin{array}{l}\text { Which one can lower } \\
\text { the quality of food? }\end{array}$ & 36 & 69.2 & 16 & 30.8 \\
\hline $\begin{array}{l}\text { How should hands be } \\
\text { washed when } \\
\text { contaminated? }\end{array}$ & 25 & 48.1 & 27 & 51.9 \\
\hline $\begin{array}{l}\text { What is the basic } \\
\text { procedure for cleaning } \\
\text { utensils and other } \\
\text { kitchen equipment? }\end{array}$ & 17 & 32.7 & 35 & 67.3 \\
\hline $\begin{array}{l}\text { Which practice is the } \\
\text { most likely to result in } \\
\text { foodborne illness? }\end{array}$ & 37 & 71.2 & 15 & 28.8 \\
\hline $\begin{array}{l}\text { Which food is good for } \\
\text { health? }\end{array}$ & 49 & 95.2 & 3 & 5.8 \\
\hline $\begin{array}{l}\text { What is the next step } \\
\text { after serving food? }\end{array}$ & 46 & 88.5 & 6 & 11.5 \\
\hline
\end{tabular}




\begin{tabular}{|c|c|c|c|c|}
\hline $\begin{array}{c}\text { How should utensils be } \\
\text { placed before and after } \\
\text { serving food? }\end{array}$ & 51 & 98.1 & 1 & 1.9 \\
\hline $\begin{array}{c}\text { According to circular of } \\
\text { the Minister of Trade of } \\
\text { the Republic of } \\
\text { Indonesia, what is the } \\
\text { maximum customer } \\
\text { capacity in the new } \\
\text { normal era? }\end{array}$ & 28 & 53.8 & 24 & 46.2 \\
\hline $\begin{array}{c}\text { What personal } \\
\text { protective equipment } \\
\text { should restaurant staff, } \\
\text { managers, and waiters } \\
\text { wear during the } \\
\text { pandemic? }\end{array}$ & 35 & 67.3 & 17 & 32.7 \\
\hline $\begin{array}{c}\text { What is the body } \\
\text { temperature of visitors } \\
\text { who are allowed to enter } \\
\text { the restaurant area? }\end{array}$ & 43 & 82.7 & 9 & 17.3 \\
\hline
\end{tabular}

Table 3. Analysis of food safety knowledge of food handlers in Medan, Indonesia

\begin{tabular}{|c|c|c|}
\hline Level of knowledge & Frequency (person(s) & Percentage (\%) \\
\hline Good & 6 & 11.5 \\
\hline Average & 38 & 73.1 \\
\hline Below Average & 8 & 15.4 \\
\hline Total & 52 & 100 \\
\hline
\end{tabular}

In this study, the food-handlers $(73.1 \%)$ had average knowledge of food safety. This corresponds with Aminah \& Hidayah (2004) where the majority of samples had average knowledge (Aminah \& Hidayah, 2006). The majority of respondents know how utensils should be handled before and after serving food ( $98.1 \%$ correct answers), the ideal condition of how food storage should be (98.1\% correct answers), and which food is healthy (95.2\% correct answers). Furthermore, cross-contamination may occur at any phase of food processing. For example, a bacterial transfer occurs not only "from meat to knife," but also "from knife to cutting surfaces." Cross-contamination is also believed to be linked to contaminated equipment and inadequate sanitation procedures (National Institute for Public Health and the Environment, 2020). The average cross-contamination rate of ready-to-eat food from hands and kitchen utensils is $2.9 \%$ to $27.5 \%$. However, the percentages of chicken legs and fillets transferred to hands ( $2.9 \%$ and $3.8 \%$, respectively), poultry fillets transferred to the cutting board and knife $(1.1 \%)$, and chicken legs transferred to the dish $(1.1 \%)$ were significantly lower $(0.3 \%)$ (Cardoso et al., 2021).

Since 2020, Indonesia government has published a lot of regulations related to COVID-19. This study shows that $82.7 \%$ of the respondents know the temperature requirement for customers which are allowed to enter restaurant areas. Therefore, the socialization of this new regulation was a success. 


\section{Food Safety Attitude}

Table 4. Assessment of food management attitude of food handlers in Medan, Indonesia

\begin{tabular}{|c|c|c|c|c|c|}
\hline \multirow[b]{2}{*}{ No } & \multirow[b]{2}{*}{ Statement } & \multicolumn{4}{|c|}{ Frequency } \\
\hline & & Agree (person (s) & $\begin{array}{c}\text { Percentage } \\
(\%)\end{array}$ & $\begin{array}{c}\text { Disagree } \\
\text { (person (s) }\end{array}$ & Percentage $(\%)$ \\
\hline 1 & $\begin{array}{l}\text { Food processors } \\
\text { should wash their } \\
\text { hands with soap } \\
\text { before cooking. }\end{array}$ & 52 & 100 & 0 & 0 \\
\hline 2 & $\begin{array}{l}\text { Food processors are } \\
\text { allowed to smoke } \\
\text { while cooking. }\end{array}$ & 1 & 1.9 & 51 & 98.1 \\
\hline 3 & $\begin{array}{l}\text { The processor must } \\
\text { use clean water that } \\
\text { meets the drinking } \\
\text { water requirements } \\
\text { for cooking. }\end{array}$ & 51 & 98.1 & 1 & 1.9 \\
\hline 4 & $\begin{array}{c}\text { Food handlers should } \\
\text { wash dishes with } \\
\text { soap and running } \\
\text { water. }\end{array}$ & 52 & 100 & 0 & 0 \\
\hline 5 & $\begin{array}{l}\text { Food processors must } \\
\text { separate raw foods } \\
\text { from cooked foods. }\end{array}$ & 50 & 96.2 & 2 & 3.8 \\
\hline 6 & $\begin{array}{l}\text { Food handlers should } \\
\text { cover finished food } \\
\text { with clean, protective } \\
\text { covers (serving } \\
\text { hoods, pot lids, etc.). }\end{array}$ & 50 & 96.2 & 2 & 3.8 \\
\hline 7 & $\begin{array}{l}\text { The handler } \\
\text { repeatedly heats the } \\
\text { processed green } \\
\text { vegetables (spinach, } \\
\text { kangkong, etc.). }\end{array}$ & 10 & 19.2 & 42 & 80.8 \\
\hline 8 & $\begin{array}{l}\text { Food processors must } \\
\text { choose good, clean } \\
\text { food ingredients. }\end{array}$ & 52 & 100 & 0 & 0 \\
\hline 9 & $\begin{array}{c}\text { Food handlers must } \\
\text { provide adequate } \\
\text { waste disposal sites. }\end{array}$ & 52 & 100 & 0 & 0 \\
\hline 10 & $\begin{array}{l}\text { Food handlers must } \\
\text { maintain the } \\
\text { cleanliness of their } \\
\text { shop. }\end{array}$ & 52 & 100 & 0 & 0 \\
\hline
\end{tabular}


Table 5. Analysis of food management attitude of food handlers in Medan, Indonesia

\begin{tabular}{|c|c|c|}
\hline Level of Attitude & Frequency (person (s) & Percentage (\%) \\
\hline Good & 48 & 92.3 \\
\hline Average & 4 & 7.7 \\
\hline Below Average & 0 & 0 \\
\hline Total & 52 & 100 \\
\hline
\end{tabular}

Table 5 showed that the majority of the respondents have a good food management attitude. This corresponds with (Aspiani \& Rustiawan, 2020) which discovered that the majority of samples have a good food management attitude. Furthermore, food handlers are aware of the importance of personal hygiene. Hand washing is critical in preventing hazardous bacteria from spreading from people's hands to their food. The biggest risk factor contributing to foodborne disease caused by food handlers has been identified as contact with bare hands and failing to wash adequately (Todd et al., 2007). A study by Lee detected Salmonella on the hands of about half of the participating food handlers. These handlers may be asymptomatic carriers for transmission, as Salmonella can remain in a carrier state up to 300 days after infection (Lee et al., 2017). This situation eventually increases the risk of food poisoning.

The results showed that food-handlers were aware of cross-contamination. This correlates with the knowledge of the respondents. Cross-contamination with Salmonella occurs in household kitchens when the same cooking equipment (particularly cutting boards) is used for raw and cooked pork preparation, even if they are washed in between. However, when a separate cutting board and knife were used to prepare raw and cooked pork, no cross-contamination was detected (Dang-Xuan, 2018).

\section{Food Safety Practice}

Table 6. Assessment of food management practice of food handlers in Medan, Indonesia

\begin{tabular}{|c|c|c|c|c|c|c|c|c|c|c|c|}
\hline \multirow[b]{2}{*}{ No } & \multirow[b]{2}{*}{ Statement } & \multicolumn{10}{|c|}{ Frequency } \\
\hline & & $\begin{array}{l}\text { Alw } \\
\text { ays } \\
\text { (pers } \\
\text { on(s) } \\
\text { ) }\end{array}$ & $\begin{array}{l}\text { Perc } \\
\text { enta } \\
\text { ge } \\
(\%)\end{array}$ & $\begin{array}{l}\text { Ofte } \\
\mathrm{n} \\
\text { (pers } \\
\text { on(s) } \\
\text { ) }\end{array}$ & $\begin{array}{c}\text { Perc } \\
\text { enta } \\
\text { ge } \\
(\%)\end{array}$ & $\begin{array}{l}\text { So } \\
\text { meti } \\
\text { mes } \\
\text { (per } \\
\text { son( } \\
\text { s)) }\end{array}$ & $\begin{array}{c}\text { Perc } \\
\text { enta } \\
\text { ge } \\
(\%)\end{array}$ & $\begin{array}{l}\text { Rar } \\
\text { ely } \\
\text { (per } \\
\text { son( } \\
\text { s)) }\end{array}$ & $\begin{array}{l}\text { Perc } \\
\text { enta } \\
\text { ge } \\
(\%)\end{array}$ & $\begin{array}{l}\mathrm{Nev} \\
\text { er } \\
\text { (per } \\
\text { son( } \\
\text { s)) }\end{array}$ & $\begin{array}{l}\text { Perc } \\
\text { enta } \\
\text { ge } \\
(\%)\end{array}$ \\
\hline 1 & $\begin{array}{l}\text { Before preparing } \\
\text { or handling food, } \\
\text { I wash hands with } \\
\text { soap and warm } \\
\text { water. }\end{array}$ & 34 & 65.4 & 12 & 23.1 & 4 & 7.7 & 2 & 3.8 & 0 & 0 \\
\hline 2 & $\begin{array}{l}\text { If I have a cut or } \\
\text { sore on my hand, } \\
\text { I cover it before } \\
\text { preparing food. }\end{array}$ & 33 & 63.5 & 12 & 23.1 & 4 & 7.7 & 2 & 3.8 & 1 & 1.9 \\
\hline 3 & $\begin{array}{l}\text { I was a plate used } \\
\text { for raw meat, } \\
\text { poultry, or } \\
\text { seafood before } \\
\text { putting cooked }\end{array}$ & 33 & 63.5 & 17 & 32.7 & 2 & 3.8 & 0 & 0 & 0 & 0 \\
\hline
\end{tabular}




\begin{tabular}{|c|c|c|c|c|c|c|c|c|c|c|c|}
\hline & $\begin{array}{c}\text { food on the plate } \\
\text { or I use a clean } \\
\text { plate. }\end{array}$ & & & & & & & & & & \\
\hline 4 & $\begin{array}{l}\text { I use the same } \\
\text { cutting board } \\
\text { when preparing } \\
\text { raw meats, } \\
\text { poultry, sea foods } \\
\text { and vegetables. }\end{array}$ & 16 & 30.8 & 8 & 15.4 & 8 & 15.4 & 5 & 9.6 & 15 & 28.8 \\
\hline 5 & $\begin{array}{l}\text { I put frozen meat } \\
\text { and poultry on the } \\
\text { counter in the } \\
\text { morning so that it } \\
\text { will be thawed } \\
\text { and ready to cook } \\
\text { in the evening. }\end{array}$ & 11 & 21.2 & 9 & 17.3 & 10 & 19.2 & 9 & 17.3 & 13 & 25 \\
\hline 6 & $\begin{array}{l}\text { I store my eggs at } \\
\text { room temperature. }\end{array}$ & 16 & 30.8 & 11 & 21.2 & 10 & 19.2 & 5 & 9.6 & 10 & 19.2 \\
\hline 7 & $\begin{array}{l}\text { I use hot, soapy } \\
\text { water to clean my } \\
\text { countertops after } \\
\text { preparing food. }\end{array}$ & 17 & 32.7 & 13 & 25 & 18 & 34.6 & 0 & 0 & 4 & 7.7 \\
\hline 8 & $\begin{array}{l}\text { I use a } \\
\text { thermometer to } \\
\text { determine the } \\
\text { temperature of the } \\
\text { refrigerator. }\end{array}$ & 7 & 13.5 & 7 & 13.5 & 12 & 23.1 & 6 & 11.5 & 20 & 38.5 \\
\hline 9 & $\begin{array}{c}\text { I throw away } \\
\text { refrigerated } \\
\text { leftovers after 3-4 } \\
\text { days }\end{array}$ & 23 & 44.2 & 12 & 23.1 & 7 & 13.5 & 3 & 5.8 & 7 & 13.5 \\
\hline 10 & $\begin{array}{l}\text { When buying } \\
\text { food, I check the } \\
\text { "sell by" and "use } \\
\text { by" dates. }\end{array}$ & 39 & 75 & 10 & 19.2 & 2 & 3.8 & 1 & 1.9 & 0 & 0 \\
\hline
\end{tabular}

Table 7. Analysis of food management practice of food handlers in Medan, Indonesia

\begin{tabular}{|c|c|c|}
\hline Level of practice & Frequency (person(s)) & Percentage (\%) \\
\hline Good & 17 & 32.7 \\
\hline Average & 28 & 53.8 \\
\hline Below Average & 7 & 13.5 \\
\hline Total & 52 & 100 \\
\hline
\end{tabular}

Table 7 showed that the majority of respondents have an average level of practice. This agrees with (Rahmayani, 2018) which observed that the majority of samples have average food management practices.

The lack of use of a thermometer to monitor refrigerator temperature as well as the thawing of frozen meat is an unsatisfactory practice in this study. Due to food handlers' lack of understanding about the 'danger zone,' or the optimal temperature for the rapid growth of germs

Copyright (O) 2022, Journal of Asian Multicultural Research for Medical and Health Science Study, Under the license CC BY-SA 4.0 
in food, these practices are still below average. Furthermore, when compared to $4{ }^{\circ} \mathrm{C}$ for lettuce, the estimated maximum growth rate $(\max )$ of presumptive Aeromonas spp. was approximately 2 times higher at $8{ }^{\circ} \mathrm{C}$ and 3 times higher at $12^{\circ} \mathrm{C}$ (Umotoni et al., 2020). In another study, it was observed that Morganella morganii concentration in M. morganii-inoculated tuna after 10 days at $37^{\circ} \mathrm{C}$ and $25^{\circ} \mathrm{C}$ was higher than that stored at $4^{\circ} \mathrm{C}$ (Ahmed, 2019).

From the food management attitude analysis, it was observed that food handlers are quite aware of cross-contamination. This can also be seen since there has been an improvement from previous study (Lubis et al., 2018) that is the number of handwashing before and after foodhandling act from $25 \%$ of respondents to $65.4 \%$ of respondents. However, in practice, the usage of a single cutting board is still ubiquitous. The probability of obtaining Campylobacter infection was favorably connected to raw chicken preparation before salad preparation, and negatively related to handwashing and cutting board washing after raw chicken preparation. This information should be taken into account when creating public campaigns to promote better food hygiene practices. These practices include emphasizing the usage of separate cutting boards or the washing of cutting boards, as well as the significance of not processing raw meat before producing ready-to-eat items (Mylius et al., 2008).

\section{Food Management Behavior}

Table 8. Analysis of food management behavior of food handlers in Medan, Indonesia

\begin{tabular}{|l|l|l|}
\hline Behavior & Frequency $($ person$(\mathbf{s}))$ & Percentage $(\%)$ \\
\hline Good & 27 & 51,9 \\
\hline Bad & 25 & 48,1 \\
\hline Total & 52 & 100 \\
\hline
\end{tabular}

Table 8 shows that the food management behavior of the majority of food handlers is good at $51.9 \%$ (27/52). However almost half of the respondents have bad food management behavior. To improve the safety of food sold, food handler training should be a priority. Other regulations and methods to improve food safety behavior should also be promoted

\section{Conclusion}

This study showed that the level of food management among food handlers is good. However, there are still chances for cross-contamination to occur. To ensure the safety of food sold, food handling training and rules should be prioritized and advocated.

\section{References}

Ahmed O.M., (2019). Histamine and Other Biogenic Amines Formation in Canned Tuna Fisih Inoculated with Morganella Morganii or Proteus Mirabilis in Determining Food Safety During Temperature Abuse. Scientia Ricerca. 3(4), 690-700.

Aminah S, \& Hidayah, N. (2006). Pengetahuan Keamanan Pangan Penjual Makanan Jajanan di Lingkungan Sekolah Kelurahan Wonodri Kecamatan Semarang Selatan Kota Semarang, Jurnal Litbang Universitas Muhammadiyah Semarang. 4(3), 19 -24.

Angolo C.M. (2011). Food safety knowledge, beliefs and self-reported handling practices of international college students at a Midwestern University [Master thesis, Kansas State University]. K-State Library. http://hdl.handle.net/2097/8865

Arisanti, R.R., Indriani, C., Wilopo, S.A. (2018). Kontribusi Agen dan Faktor Penyebab Kejadian Luar Biasa Keracunan Pangan di Indonesia: Kajian Sistematis. Berita Kedokteran Masyarakat, 34, 99-106. https://doi.org/10.22146/bkm.33852 
Aspiani M, \& Rustiawan, A. (2020). Hubungan Pengetahuan, Sikap Penjamah Makanan dan Fasilitas Sanitasi terhadap Keamanan Pangan di Rumah Makan Kawasan Wisata Kuliner Pantai Depok Kabupaten Bantul Tahun 2019. The $11^{\text {th }}$ University Research Colloquium 2020. http://repository.urecol.org/index.php/proceeding/article/view/877/852

Augustin, E. (2015). Gambaran Pengetahuan, Sikap dan Tindakan Higiene Sanitasi Pedagang Makanan Jajanan di Sekolah Dasar Cipinang Besar Utara Kotamadya Jakarta Timur Tahun 2014 Undergraduate thesis, Universitas Islam Negeri Syarif Hidayatullah], Institutional Repository UIN $\quad$ Syarif $\quad$ Hidayatullah. https://repository.uinjkt.ac.id/dspace/handle/123456789/28943.

Badan Pengawas Obat dan Makanan Medan. (2019). Laporan Tahunan 2019 Balai Besar POM di Medan. Medan, Badan Pengawas Obat dan Makanan Medan, Medan.

Badan Pengawas Obat dan Makanan RI. (2020). Pedoman Produksi dan Distribusi Pangan Olahan pada Masa Status Darurat Kesehatan Corona Virus Disease (COVID-19) di Indonesia. Badan Pengawas Obat dan Makanan RI, Jakarta.

Cardoso, M. J., Ferreira, V., Truninger, M., Maia, R., \& Teixeira, P. (2021). Crosscontamination events of Campylobacter spp. in domestic kitchens associated with consumer handling practices of raw poultry. International journal of food microbiology, 338, 108984. https://doi.org/10.1016/j.ijfoodmicro.2020.108984

Chlebicz, A., \& Śliżewska, K. (2018). Campylobacteriosis, Salmonellosis, Yersiniosis, and Listeriosis as Zoonotic Foodborne Diseases: A Review. International journal of environmental research and public health, 15(5), 863. https://doi.org/10.3390/ijerph15050863

Dang-Xuan, S., Nguyen-Viet, H., Pham-Duc, P., Grace, D., Unger, F., Nguyen-Hai, N., Nguyen-Tien, T., \& Makita, K. (2018). Simulating Cross-Contamination of Cooked Pork with Salmonella enterica from Raw Pork through Home Kitchen Preparation in Vietnam. International journal of environmental research and public health, 15(10), 2324. https://doi.org/10.3390/ijerph15102324

Gibney, M.J., Lanham-New, S.A., Cassidy, A., \& Vorster, H.H. (2009). Introduction to Human Nutrition Second Edition, Wiley, Chichester.

https://jurnal.unimus.ac.id/index.php/LITBANG/article/view/202/203

Kadariya, J., Smith, T. C., \& Thapaliya, D. (2014). Staphylococcus aureus and staphylococcal food-borne disease: an ongoing challenge in public health. BioMed research international, 2014, 827965. https://doi.org/10.1155/2014/827965

Lee, H. K., Abdul Halim, H., Thong, K. L., \& Chai, L. C. (2017). Assessment of Food Safety Knowledge, Attitude, Self-Reported Practices, and Microbiological Hand Hygiene of Food Handlers. International Journal of Environmental Research and Public Health, 14(1), 55. https://doi.org/10.3390/ijerph14010055

Lubis, N., Amelia, S., Arrasyid, N. \& Rozi, M. (2018). Bacterial Assessment among Traditional Food Handlers and Their Behavior Related to Hygiene and Sanitation. International Conference of Science, Technology, Engineering, Environmental and Ramification Researches. 1, 462 - 466. doi:10.5220/0010073404620466 
Mylius, S.D., Nauta, M.J. \& Havelaar, A.H. (2008). Cross-contamination during food preparation: A mechanistic model applied to chicken-borne Campylobacter. Risk Analysis: An International Journal. 27, 803-813.

National Institute for Public Health and the Environment (RIVM), The Netherlands, Iulietto, M. F., \& Evers, E. G. (2020). Modelling and magnitude estimation of crosscontamination in the kitchen for quantitative microbiological risk assessment (QMRA). EFSA journal. European Food Safety Authority, 18(Suppl 1), e181106. https://doi.org/10.2903/j.efsa.2020.e181106

Ncube, F., Kanda, A., Chijokwe, M., Mabaya, G., \& Nyamugure, T. (2020). Food safety knowledge, attitudes and practices of restaurant food handlers in a lower-middleincome country. Food science \& nutrition, 8(3), 1677-1687. https://doi.org/10.1002/fsn3.1454

Rahmayani, R. (2018). Hubungan pengetahuan, sikap dan tindakan hygiene sanitasi pedagang makanan jajanan di pinggir jalan. AcTion: Aceh Nutrition Journal, 3(2), 172-178. doi:http://dx.doi.org/10.30867/action.v3i2.84

Todd, E. C., Greig, J. D., Bartleson, C. A., \& Michaels, B. S. (2007). Outbreaks where food workers have been implicated in the spread of foodborne disease. Part 3. Factors contributing to outbreaks and description of outbreak categories. Journal of food protection, 70(9), 2199-2217. https://doi.org/10.4315/0362-028x-70.9.2199

Umutoni, N., Jakobsen, A.N., Mukhatov, K., Thomassen, G.M.B., Karlsen H., Mehli L. (2020). Occurrence, diversity and temperature-dependent growth kinetics of Aeromonas spp. in lettuce, International Journal of Food Microbiology, 335, 108852. https://doi.org/10.1016/j.ijfoodmicro.2020.108852.

World Health Organization. (2002). Penyakit Bawaan Makanan. EGC, Jakarta.

World Health Organization. (2003). The present state offoodborne disease in OECD countries. WHO Document Production Services, Geneva

World Health Organization. (2015). WHO Estimates of The Global Burden of Foodborne Disease: Foodborne Disease Burden Epidemiology Reference Group 2007 - 2015. World Health Organization. https://apps.who.int/iris/handle/10665/199350

World Health Organization. (2020). Food Safety.https://www.who.int/health-topics/foodsafety 